\title{
Socio-demographic profile of HIV/AIDS patients at ART centres in Chennai
}

\author{
T Uma ${ }^{*}$, Parameswari Srijayanth', S Valarmathi', S Sekar², N Kabilan', Mayilvahanan Natarajan \\ From First International Science Symposium on HIV and Infectious Diseases (HIV SCIENCE 2012) \\ Chennai, India. 20-22 January 2012
}

\section{Background}

To study the socio-demographic status of HIV patients in ART centres, Chennai, Tamilnadu.

\section{Methods}

After obtaining informed consent, a semi-structured questionnaire was administered to adult HIV patients attending ART centers, Chennai. Their demographic details, personal history, behavioral pattern were studied between June-October 2011.

\section{Results}

Out of 296 patients, 117 were male, 174 were female and 5 were transgender. $77.4 \%$ of them were between the age group of 18-41. Among all, 20.6\% were illiterate and $79.4 \%$ were literate. Among the literates, $5.7 \%$ were graduates. In men, $77.8 \%$ were married. Among married males $5.1 \%$ were separated and $7.7 \%$ were widowers. In women, $97.7 \%$ were married. Among them $29.9 \%$ were widow and $9.8 \%$ were separated. $84.4 \%$ of male and $28.1 \%$ of female were employed. $56.6 \%$ were daily wagers. $57.7 \%$ were earning $<4000$ rs per month. Livelihood of $71.9 \%$ females was supported by others, $32.2 \%$ were housewives. $57 \%$ of patients were in a nuclear family and $7.4 \%$ of them were in broken family. $67.5 \%$ of the male have at least any one of habits like alcohol, smoking and intravenous drug usage. $71 \%$ males and $15.6 \%$ females had multiple sexual partners. Among males, $10.25 \%$ were homosexuals and $1.7 \%$ was heterosexuals. $53.9 \%$ of patients use safe drinking water.

\footnotetext{
* Correspondence: siddhauma@gmail.com

'Department of Epidemiology, The Tamilnadu Dr. MGR Medical University, India
}

Full list of author information is available at the end of the article

\section{Conclusion}

Low socio-economic status with high risk behaviour and lack of awareness were prevailing among the HIV patients. Epidemiological studies should be carried out in various settings to understand the role of socio economic status to control the transmission of HIV/AIDS.

\section{Author details}

'Department of Epidemiology, The Tamilnadu Dr. MGR Medical University, India. ${ }^{2}$ Senior Medical Officer, ART centre, Madras Medical College, Chennai, India.

Published: 4 May 2012

\section{doi:10.1186/1471-2334-12-S1-P53}

Cite this article as: Uma et al:: Socio-demographic profile of HIV/AIDS patients at ART centres in Chennai. BMC Infectious Diseases 2012 12(Suppl 1):P53.
Submit your next manuscript to BioMed Central and take full advantage of:

- Convenient online submission

- Thorough peer review

- No space constraints or color figure charges

- Immediate publication on acceptance

- Inclusion in PubMed, CAS, Scopus and Google Scholar

- Research which is freely available for redistribution

Submit your manuscript at www.biomedcentral.com/submit
C Biomed Central
C Biomed Central

(c) 2012 Uma et al; licensee BioMed Central Ltd. This is an Open Access article distributed under the terms of the Creative Commons Attribution License (http://creativecommons.org/licenses/by/2.0), which permits unrestricted use, distribution, and reproduction in any medium, provided the original work is properly cited. 